\title{
In Vivo Immunomodulation and Lipid Peroxidation Activities Contributed to Chemoprevention Effects of Fermented Mung Bean against Breast Cancer
}

\author{
Swee Keong Yeap, ${ }^{1}$ Hamidah Mohd Yusof, ${ }^{2}$ Nurul Elyani Mohamad, \\ Boon Kee Beh, ${ }^{3}$ Wan Yong Ho, ${ }^{2}$ Norlaily Mohd Ali, ${ }^{2}$ Noorjahan Banu Alitheen, ${ }^{2}$ \\ Soo Peng Koh, ${ }^{4}$ and Kamariah Long ${ }^{4}$ \\ ${ }^{1}$ Institute of Bioscience, Universiti Putra Malaysia, Serdang, Selangor, Malaysia \\ ${ }^{2}$ Department of Cell and Molecular Biology, Faculty of Biotechnology and Biomolecular Science, Universiti Putra Malaysia, \\ 43400 Serdang, Selangor, Malaysia \\ ${ }^{3}$ Department of Bioprocess Technology, Faculty of Biotechnology and Biomolecular Science, Universiti Putra Malaysia, \\ 43400 Serdang, Selangor, Malaysia \\ ${ }^{4}$ Biotechnology Research Centre, Malaysian Agricultural Research and Development Institute (MARDI), 43400 Serdang, \\ Selangor, Malaysia
}

Correspondence should be addressed to Kamariah Long; amai@mardi.gov.my

Received 28 January 2013; Accepted 2 April 2013

Academic Editor: André-Michael Beer

Copyright (C) 2013 Swee Keong Yeap et al. This is an open access article distributed under the Creative Commons Attribution License, which permits unrestricted use, distribution, and reproduction in any medium, provided the original work is properly cited.

\begin{abstract}
Mung bean has been reported to have antioxidant, cytotoxic, and immunomodulatory effects in vitro. Fermented products are reported to have enhanced immunomodulation and cancer chemopreventive effects. In this study, fermented mung bean treatments in vivo were studied by monitoring tumor development, spleen immunity, serum cytokine (interleukin 2 and interferon gamma) levels, and spleen/tumor antioxidant levels after injection with low and high risk 4T1 breast cancer cells. Pretreatment with fermented mung bean was associated with delayed tumor formation in low risk mice. Furthermore, this treatment was connected with higher serum anticancer cytokine levels, spleen $\mathrm{T}$ cell populations, splenocyte cytotoxicity, and spleen/tumor antioxidant levels. Histopathological evaluation of fermented mung bean treated tumor revealed lower event of mitotic division. On the other hand, antioxidant and nitric oxide levels that were significantly increased in the untreated mice were inhibited in the fermented mung bean treated groups. These results suggested that fermented mung bean has potential cancer chemoprevention effects through the stimulation of immunity, lipid peroxidation, and anti-inflammation.
\end{abstract}

\section{Introduction}

Breast cancer is the most common type of cancer and has higher incidence in industrialized countries like Europe and United State than in developing countries such as China and India. This phenomenon has been related to different life style especially to the Asian diet and their food preparation methods [1]. Natural food ingredients with relatively low toxicities commonly consumed in the Asian diet which carries relatively low toxicity have been proposed as one of the best chemopreventive strategies to battle cancer [2].
Fermentation is one of the oldest and most common methods to preserve food in Asia [3]. Fermented foods project a natural and healthy image of Asian diet [3] and are found to possess chemopreventive effects against breast cancer which had been related to the immunostimulatory effects of fermented products [4].

Mung bean (Vigna radiate), commonly known as "green gram," is a common source of protein in the Asian diet [5]. A previous study had reported the in vitro cytotoxicity and immunomodulatory effects of mung bean sprout thus indicating it as a potential nutraceutical agent against cervical 
and liver cancers. Mung bean sprout extract had been found to stimulate tumor necrosis factor-alpha (TNF- $\alpha$ ) and interferon gamma (IFN- $\gamma$ ) which consequently stimulated cell-mediated immunity. Furthermore, mung bean sprouts extract also induced cell cycle arrest and apoptosis on the tested cancer cells [6]. Besides germination, products that contained enzyme hydrolysed [7] or fermented [8] mung bean have also been identified as potential cancer chemopreventive or therapeutic agents. We have previously reported that fermentation can significantly improve GABA content of mung bean [9]. GABA has been reported to inhibit cholangiocarcinoma [10] and leukemia cells [11]. To date, the roles of the antioxidant and immunomodulatory effects of GABA enriched fermented mung bean in the prevention of breast cancer are still not fully understood. Thus, this study was aimed at evaluating the antioxidant, chemopreventive, and immunostimulatory effects of GABA enriched fermented mung bean extract on low and high risk $4 \mathrm{Tl}$ injected mice.

\section{Materials and Methods}

2.1. Chemicals and Antibodies. Phosphate buffer saline (PBS), Folin-Ciocalteu reagent, hypoxanthine, xanthine oxidase, superoxide dismutase, and tamoxifen (positive control) were purchased from Sigma-Aldrich, USA. Griess reagent was obtained from Invitrogen, USA. Foetal bovine serum (FBS) was purchased from PAA, Austria. Fluorescein (FITC) conjugated anti-mouse CD4 and Phycoerythrin (PE) conjugated anti-mouse CD8 antibodies, mouse interleukin 2 (IL-2), interferon gamma (IFN- $\gamma$ ), and tumor necrosis factor (TNF$\alpha)$ ELISA kits were purchased from BioLegend, USA. Rhizopus sp.strain 5351 inoculums were obtained from the culture collection center of the Malaysian Agricultural Research and Development Institute (MARDI).

2.2. Cell Preparation. Yac-1 and $4 \mathrm{~T} 1$ cell lines were purchased from ATCC, USA. Both cell lines were maintained in RPMI1640 medium with $10 \% \mathrm{FBS}$ at $37^{\circ} \mathrm{C}, 5 \% \mathrm{CO}_{2}$.

2.3. Fermentation of Mung Bean. Fermentation of mung bean and the content of GABA were carried out according to our previous report [9]. The fermented mung bean contained $0.122 \mathrm{~g} / 100 \mathrm{~g}$ of dried fermented mung bean powder.

2.4. Animals. Female Balb/c mice of 8 weeks old were purchased from the Institute of Bioscience, Universiti Putra Malaysia, and were housed under 12 hours of light and darkness and fed with standard laboratory pellet diet and water ad libitum. This study was approved by the Animal Care and Use Committee of Universiti Putra Malaysia.

2.5. In Vivo Breast Cancer Development Experiment. Mice (total of 72 mice, $n=8$ per group) were separated to 9 groups and pretreated with either PBS (Groups 1-3), tamoxifen ( $1 \mathrm{mg} / \mathrm{kg}$ body weight) (Groups 4 and 5), $200 \mathrm{mg} / \mathrm{kg}$ body weight (Groups 6 and 7), or $1000 \mathrm{mg} / \mathrm{kg}$ body weight (Groups 8 and 9) of fermented mung bean extract p.o. for 30 days continuously. On day 30 after treatment, 4T1 cells were harvested and inoculated s.c. on the upper portion of the right hind thigh of mouse with either $1 \times 10^{6}$ (high risk for Groups 3, 5, 7, and 9), or $1 \times 10^{4}$ (low risk for Groups $2,4,6$, and 8) viable cells. Group 1 was injected with PBS and served as normal control. Mice were monitored for 14 days and treatments were continued during this period. Mice were weighted and tumor sizes were measured every 3 days. Tumor volume was calculated according to the following formula: tumor volume $=0.5 \times\left(W^{2} \times L\right)(W=$ smaller perpendicular diameter $; L=$ larger perpendicular diameter) [12]. On day 21 postinoculation of the $4 \mathrm{~T} 1$ cells, all mice were anesthetised with $2 \%$ isoflurane (Merck) and sacrificed by cervical dislocation. Spleen, tumor, and serum were collected and subjected to the following assays.

2.5.1. Immunophenotyping of Spleen CD4 and CD8 T Cells. Spleen was harvested, washed with PBS 3 times, and pressed through $80 \mu \mathrm{m}$ sterile wire mesh. The filtrate was then pelleted, treated with lysis buffer $\left(8 \mathrm{~g} \mathrm{NH}_{4} \mathrm{Cl}, 1 \mathrm{~g} \mathrm{Na}_{2}\right.$ EDTA, $0.1 \mathrm{KH}_{2} \mathrm{PO}_{4}$, pH 7.4), and washed with PBS. Then, splenocytes were stained with $10 \mu \mathrm{g} / 10 \mu \mathrm{L}$ of CD4-FITC and CD8$\mathrm{PE}$ antibodies. After that, cells were washed 3 times and resuspended in PBS and subjected to flow cytometry analysis using FACSCalibur flow cytometer (BD, USA).

2.5.2. Splenocyte Cytotoxicity Assay. Isolated splenocytes (Effector-E) were cocultured with Yac-1 (Target-T) cell in the ratio of $\mathrm{E}: \mathrm{T}$ at $2: 1$ and $10: 1$. The cytotoxicities of splenocytes from different treatments were determined using the CytoTox 96 nonradioactive cytotoxicity assay kit (Promega, USA) and the percentage of cytotoxicity was calculated according to the user manual [13]. Each sample was assayed in triplicates.

2.5.3. Serum IL-2 and IFN- $\gamma$ Levels. Collected blood was spun at $8000 \mathrm{~g}$ for 5 minutes and subjected to IL-2 and IFN- $\gamma$ determination using the ELISA kit (BioLegend, USA) according to the user's manual [13]. Each sample was assayed for triplicates.

2.5.4. Spleen and Tumor Antioxidant and NO Levels. Harvested spleen and tumor were homogenized in ice-cold PBS by passing through $80 \mu \mathrm{m}$ sterile wire mesh. All filtrates were pelleted and the supernatants from the spleen and tumor of all groups were subjected to superoxide dismutase (SOD), malondialdehyde (MDA), and nitric oxide (NO) assays [9].

2.5.5. Tumor Histopathology Evaluation. Harvested tumor was fixed ( $10 \%$ formalin), embedded in paraffin, sectioned, stained with haematoxylin and eosin, and viewed using bright-field microscope for histopathological changes according to [9].

2.6. Statistical Analysis. The results were expressed as mean \pm standard deviation (S.D.) and one-way ANOVA followed by Duncan test to analyse the significant level of the treated group compared to the untreated Groups 2 and 3, respectively. 


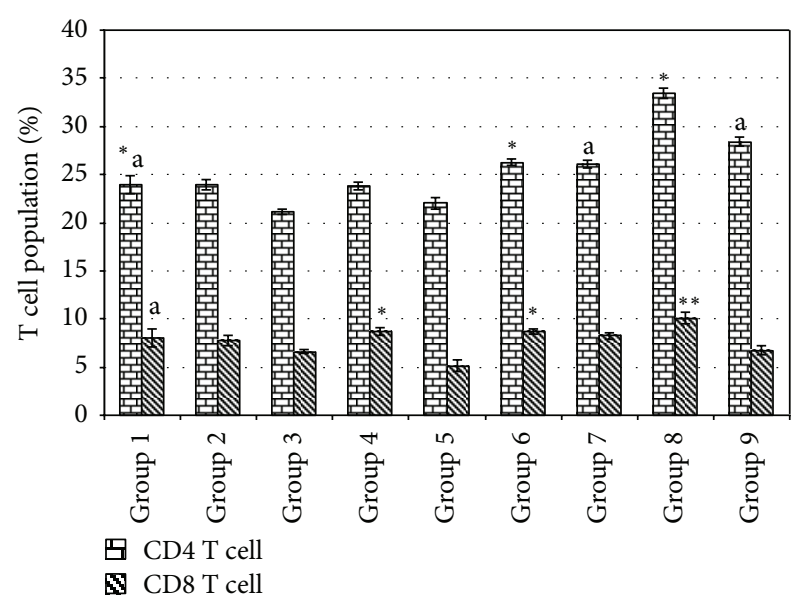

FIgURE 1: CD4 and CD8 immunophenotyping of spleen from different treatment groups on day 21 after $4 \mathrm{~T} 1$ cell inoculation. Each value represents the means \pm S.D. for three mice in triplicate each. The differences between the control or treated group and untreated group were determined by one-way ANOVA ( ${ }^{*}$ for low risk groups while ${ }^{\text {a }}$ for high risk groups; $P \leq 0.05$ ). Group 1: normal mice; Group 2: untreated $1 \times 10^{4} 4 \mathrm{~T} 1$ cell (low risk) inoculated mice; Group 3: untreated $1 \times 10^{6} 4 \mathrm{~T} 1$ cell (high risk) mice; Group 4: tamoxifen ( $1 \mathrm{mg} / \mathrm{kg}$ b.w.) treated $1 \times 10^{4} 4 \mathrm{~T} 1$ cell (low risk) inoculated mice; Group 5: tamoxifen $\left(1 \mathrm{mg} / \mathrm{kg}\right.$ b.w.) treated $1 \times 10^{6}$ 4T1 cell (high risk) inoculated mice; Group 6: fermented mung bean $\left(200 \mathrm{mg} / \mathrm{kg}\right.$ b.w.) treated $1 \times 10^{4} 4 \mathrm{~T} 1$ cell (low risk) inoculated mice; Group 7: fermented mung bean $(200 \mathrm{mg} / \mathrm{kg}$ b.w. $)$ treated $1 \times 10^{6}$ 4 T1 cell (high risk) inoculated mice; Group 8: fermented mung bean $\left(1000 \mathrm{mg} / \mathrm{kg}\right.$ b.w.) treated $1 \times 10^{4} 4 \mathrm{~T} 1$ cell (low risk) inoculated mice; Group 9: fermented mung bean (1000 mg/kg b.w.) treated $1 \times 10^{6} 4 \mathrm{~T} 1$ cell (high risk) inoculated mice.

\section{Results}

3.1. Body Weight and Tumor Size Monitoring. As is shown in Table 1, reduction of body weight was correlated well with the increment of tumor size throughout the experiment. Treatments with high concentrations of fermented mung bean and tamoxifen were able to delay the formation of tumor in the low risk group of mice. In the case of the high risk group of mice, these treatments only helped to reduce the size of the tumor throughout the experimental period. Low concentration of fermented mung bean was less effective against reduction of tumor size in the high risk group of tumor.

3.2. Spleen CD4 and CD8 T Cell Immunophenotyping. Flow cytometry CD4 and CD8 T cell immunophenotyping was carried out to evaluate the influence of fermented mung bean treatment on the change of the $\mathrm{T}$ cell population in the spleen. Tamoxifen treated groups showed similar percentages of both CD4 and CD8 T cells as compared to the untreated groups. On the other hand, fermented mung bean was able to increase both the CD4 and the CD8 $\mathrm{T}$ cell populations in a dosagedependent manner (Figure 1).

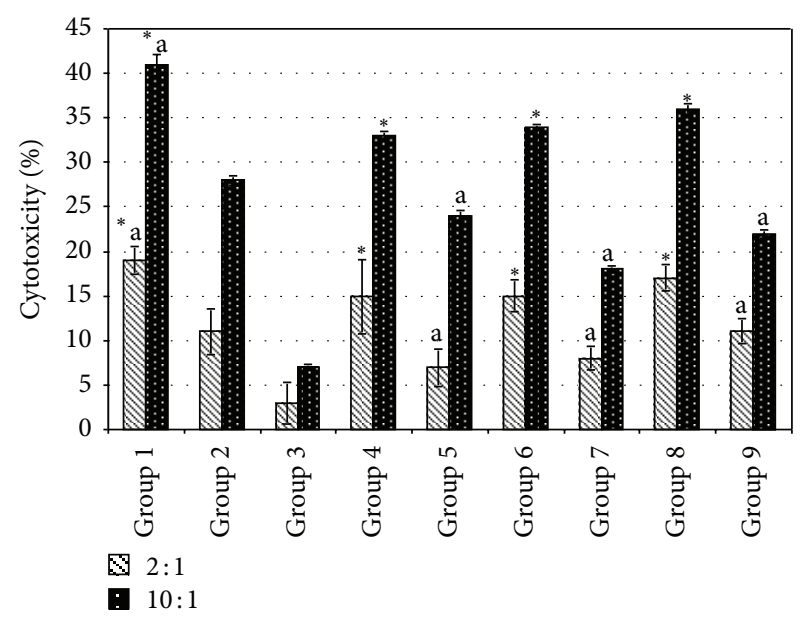

Figure 2: Cytotoxicity level of splenocyte on Yac-1 at E: T ratio of $2: 1$ and $10: 1$ from different treatment groups on day 21 after $4 \mathrm{~T} 1$ cell inoculation. Each value represents the means \pm S.D. for three mice in triplicate each. The differences between the control or treated group and untreated group were determined by one-way ANOVA ( ${ }^{*}$ for low risk groups while a for high risk groups; $P \leq 0.05$ ). Group 1: normal mice; Group 2: untreated $1 \times 10^{4} 4 \mathrm{~T} 1$ cell (low risk) inoculated mice; Group 3: untreated $1 \times 10^{6} 4 \mathrm{~T} 1$ cell (high risk) mice; Group 4: tamoxifen ( $1 \mathrm{mg} / \mathrm{kg}$ b.w.) treated $1 \times 10^{4} 4 \mathrm{~T} 1$ cell (low risk) inoculated mice; Group 5: Tamoxifen $(1 \mathrm{mg} / \mathrm{kg}$ b.w. $)$ treated $1 \times 10^{6}$ $4 \mathrm{~T} 1$ cell (high risk) inoculated mice; Group 6: fermented mung bean $\left(200 \mathrm{mg} / \mathrm{kg}\right.$ b.w.) treated $1 \times 10^{4} 4 \mathrm{~T} 1$ cell (low risk) inoculated mice; Group 7: fermented mung bean $(200 \mathrm{mg} / \mathrm{kg}$ b.w. $)$ treated $1 \times 10^{6}$ $4 \mathrm{~T} 1$ cell (high risk) inoculated mice; Group 8: fermented mung bean (1000 mg/kg b.w.) treated $1 \times 10^{4} 4 \mathrm{~T} 1$ cell (low risk) inoculated mice; Group 9: fermented mung bean $(1000 \mathrm{mg} / \mathrm{kg}$ b.w. $)$ treated $1 \times 10^{6} 4 \mathrm{~T} 1$ cell (high risk) inoculated mice.

3.3. Spleen Cytotoxicity Assay. Cocultivation of splenocyte with Yac-1 cell was used to evaluate the cytotoxicity of the splenocyte on day 21 following inoculation of $4 \mathrm{~T} 1$ cell. A higher ratio of effector (splenocytes) was associated with greater cytotoxicity against Yac-1 cells. However, this effect was significantly $(P<0.05)$ lower in the untreated mice. Treatments with both tamoxifen and fermented mung bean were able to maintain higher levels of splenocyte cytotoxicity as compared to the untreated group of mice (Figure 2).

\subsection{Serum IL-2 and IFN- $\gamma$ ELISA Quantification. Mean} serum IL-2 and IFN- $\gamma$ levels were reduced in untreated 4T1 inoculated mice especially in the high risk untreated mice (Group 3) (Figure 3). Fermented mung bean was able to restore the production of both IL- 2 and IFN- $\gamma$ in a dosagedependent manner for the low risk group of mice. Fermented mung bean restored less IL- 2 and IFN- $\gamma$ production but the levels of these cytokines were still higher than those in the untreated and the tamoxifen treated high risk group of mice.

\subsection{Spleen and Tumor Antioxidant and NO Determination.} Lipid peroxidation, antioxidant level, and inflammation of spleen and tumor were measured by MDA, SOD, and NO quantifications, respectively. Figures 4, 5, and 6 show the 
TABLE 1: Body weight $(\mathrm{g})$ and tumor volume $\left(\mathrm{mm}^{3}\right)$ changes after inoculation of $4 \mathrm{~T} 1$ cell up to day 21 . Each value represents the means \pm S.D. for six mice in triplicate each. The differences between the control or treated group and untreated group were determined by one-way ANOVA.

\begin{tabular}{|c|c|c|c|c|c|c|c|}
\hline & \multicolumn{4}{|c|}{ Body weight (g) } & \multicolumn{3}{|c|}{ Tumor volume $\left(\mathrm{mm}^{3}\right)$} \\
\hline & Day 0 & Day 7 & Day 14 & Day 21 & Day 7 & Day 14 & Day 21 \\
\hline Group 1 & $20.12 \pm 1.21$ & $22.34 \pm 0.68$ & $23.21 \pm 0.79^{* a}$ & $25.14 \pm 0.79^{* a}$ & - & - & - \\
\hline Group 2 & $21.53 \pm 1.08$ & $20.11 \pm 0.92$ & $20.14 \pm 0.91$ & $18.64 \pm 1.33$ & $70.17 \pm 6.77$ & $200.33 \pm 11.51$ & $400.35 \pm 13.41$ \\
\hline Group 3 & $20.75 \pm 1.33$ & $19.24 \pm 1.13$ & $17.26 \pm 1.57$ & $14.32 \pm 1.69$ & $300.63 \pm 21.32$ & $500.51 \pm 21.82$ & $800.68 \pm 28.92$ \\
\hline Group 4 & $20.12 \pm 0.96$ & $21.32 \pm 1.24$ & $21.53 \pm 1.82$ & $23.21 \pm 1.35^{*}$ & - & $50.12 \pm 8.31^{*}$ & $100.62 \pm 9.93^{*}$ \\
\hline Group 5 & $20.23 \pm 0.77$ & $20.76 \pm 0.88$ & $21.43 \pm 1.33^{\mathrm{a}}$ & $21.33 \pm 0.91^{\mathrm{a}}$ & $150.55 \pm 9.25^{\mathrm{a}}$ & $400.38 \pm 26.51$ & $540.58 \pm 16.79^{a}$ \\
\hline Group 6 & $20.18 \pm 0.82$ & $21.13 \pm 1.23$ & $21.57 \pm 0.86$ & $21.57 \pm 1.33^{*}$ & $50.42 \pm 6.17$ & $100.22 \pm 11.51^{*}$ & $270.71 \pm 21.36^{*}$ \\
\hline Group 7 & $21.96 \pm 1.11$ & $20.11 \pm 1.77$ & $18.89 \pm 1.59$ & $15.83 \pm 1.72$ & $230.36 \pm 12.45^{\mathrm{a}}$ & $400.56 \pm 18.35$ & $750.92 \pm 31.44$ \\
\hline Group 8 & $20.15 \pm 1.12$ & $21.53 \pm 0.94$ & $21.16 \pm 1.16$ & $22.22 \pm 0.94^{*}$ & - & $60.11 \pm 8.92^{*}$ & $100.91 \pm 11.31^{*}$ \\
\hline Group 9 & $20.84 \pm 0.94$ & $20.18 \pm 1.26$ & $19.11 \pm 1.99$ & $18.55 \pm 0.89^{\mathrm{a}}$ & $170.72 \pm 13.55^{\mathrm{a}}$ & $300.21 \pm 21.33^{\mathrm{a}}$ & $600.39 \pm 25.68^{\mathrm{a}}$ \\
\hline
\end{tabular}

Group 1: normal mice; Group 2: untreated $1 \times 10^{4} 4 \mathrm{~T} 1$ cell (low risk) inoculated mice; Group 3: untreated $1 \times 10^{6} 4 \mathrm{~T} 1$ cell (high risk) mice; Group 4: tamoxifen $\left(1 \mathrm{mg} / \mathrm{kg}\right.$ b.w.) treated $1 \times 10^{4} 4 \mathrm{~T} 1$ cell (low risk) inoculated mice; Group 5: tamoxifen $(1 \mathrm{mg} / \mathrm{kg}$ b.w. $)$ treated $1 \times 10^{6} 4 \mathrm{~T} 1$ cell (high risk) inoculated mice; Group 6: fermented mung bean $\left(200 \mathrm{mg} / \mathrm{kg}\right.$ b.w.) treated $1 \times 10^{4} 4 \mathrm{Tl}$ cell (low risk) inoculated mice; Group 7: fermnted mung bean $\left(200 \mathrm{mg} / \mathrm{kg} \mathrm{b.w.)} \mathrm{treated} 1 \times 10^{6}\right.$ 4T1 cell (high risk) inoculated mice; Group 8: fermented mung bean $\left(1000 \mathrm{mg} / \mathrm{kg}\right.$ b.w.) treated $1 \times 10^{4} 4 \mathrm{~T} 1$ cell (low risk) inoculated mice; Group 9: fermented mung bean $\left(1000 \mathrm{mg} / \mathrm{kg}\right.$ b.w.) treated $1 \times 10^{6} 4 \mathrm{Tl}$ cell (high risk) inoculated mice.

${ }^{*}$ For low risk groups while ${ }^{a}$ for high risk groups; $P \leq 0.05$.

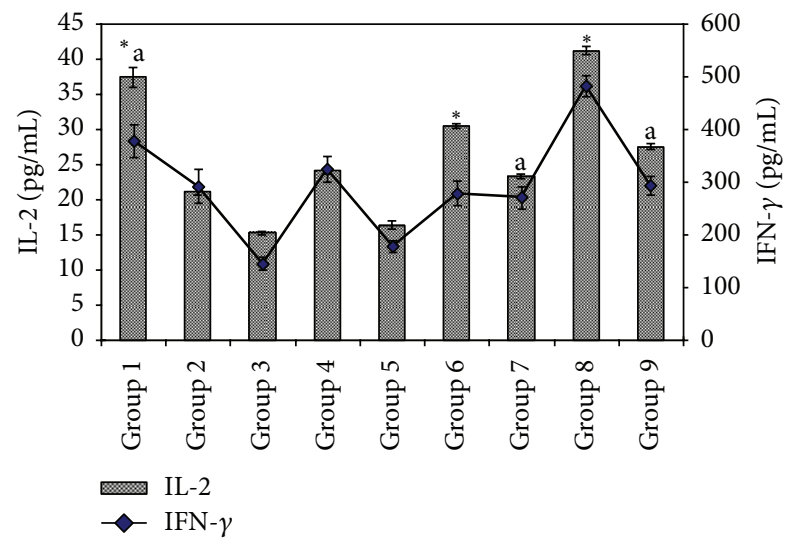

Figure 3: Serum levels of IL-2 and IFN- $\gamma$ (pg/mL) from different treatment groups on day 21 after $4 \mathrm{~T} 1$ cell inoculation. Each value represents the means \pm S.D. for three mice in triplicate each. The differences between the control or treated group and untreated group were determined by one-way ANOVA ( ${ }^{*}$ for low risk groups while ${ }^{a}$ for high risk groups; $P \leq 0.05$ ). Group 1: normal mice; Group 2: untreated $1 \times 10^{4} 4 \mathrm{~T} 1$ cell (low risk) inoculated mice; Group 3: untreated $1 \times 10^{6} 4 \mathrm{~T} 1$ cell (high risk) mice; Group 4: tamoxifen $\left(1 \mathrm{mg} / \mathrm{kg}\right.$ b.w.) treated $1 \times 10^{4} 4 \mathrm{~T} 1$ cell (low risk) inoculated mice; Group 5: Tamoxifen $\left(1 \mathrm{mg} / \mathrm{kg} \mathrm{b.w}\right.$.) treated $1 \times 10^{6}$ $4 \mathrm{~T} 1$ cell (high risk) inoculated mice; Group 6: fermented mung bean $\left(200 \mathrm{mg} / \mathrm{kg}\right.$ b.w.) treated $1 \times 10^{4} 4 \mathrm{~T} 1$ cell (low risk) inoculated mice; Group 7: fermented mung bean $(200 \mathrm{mg} / \mathrm{kg}$ b.w. $)$ treated $1 \times 10^{6}$ $4 \mathrm{~T} 1$ cell (high risk) inoculated mice; Group 8: fermented mung bean $\left(1000 \mathrm{mg} / \mathrm{kg}\right.$ b.w.) treated $1 \times 10^{4} 4 \mathrm{~T} 1$ cell (low risk) inoculated mice; Group 9: fermented mung bean $\left(1000 \mathrm{mg} / \mathrm{kg}\right.$ b.w.) treated $1 \times 10^{6} 4 \mathrm{~T} 1$ cell (high risk) inoculated mice.

SOD, MDA, and NO levels of spleen and tumor from different treatment groups on day 21 after inoculation of $4 \mathrm{~T} 1$ cells. Untreated mice from both low and high risk groups were recorded to have drastic increases of antioxidant enzyme
SOD and NO levels indicating that progression of cancer was linked with higher level of antioxidant and inflammation in not only the tumor microenvironment but also in the spleen. On top of this, lipid peroxidation which is indicated by MDA level was drastically reduced. Tamoxifen and fermented mung bean treatments successfully reduced the SOD and NO levels while increasing the lipid peroxidation in both the spleen and tumor of both the low and high risk groups of tumor.

3.6. Tumor Histopathology. Tumor histology was performed to evaluate the chemopreventive effects of fermented mung bean and tamoxifen. Mitoses were frequently observed in the tumors of the untreated high and low risk groups of mice (Figure 7). Treatments with tamoxifen and high concentration of fermented mung bean were able to reduce mitotic division in the tumors of the low risk group of mice.

\section{Discussion}

To date, breast cancer still forms the highest percentage among all types of cancer in women [14]. Generally, surgery, radiotherapy, hormonaltherapy, and chemotherapy are the conventional treatments for breast cancer. However, these treatments are always associated with relapse and treatmentinduced side effects [15]. Thus, the search for novel agents that can help to reduce the risk of breast cancer incidence is of utmost importance. Chemoprevention denotes the ability to inhibit and reduce tumorigenesis [16]. A previous survey has reported that a high percentage of postmenopausal women with or without history of breast cancer has been utilizing complementary and alternative medicines [15]. In diet based complementary and alternative medicines, many plants that contain various phytochemicals have been identified as good source of chemopreventive agents [16]. Insufficient intake of 


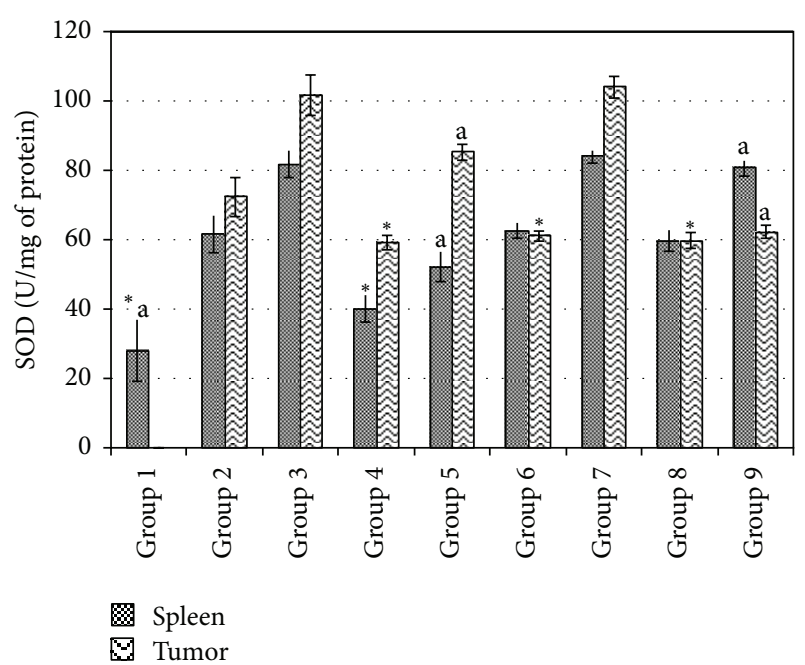

FIGURE 4: SOD level of tumor and spleen homogenate from different treatment groups on day 21 after $4 \mathrm{~T} 1$ cell inoculation. Each value represents the means \pm S.D. for three mice in triplicate each. The differences between the control or treated group and untreated group were determined by one-way ANOVA $\left({ }^{*}\right.$ for low risk groups while ${ }^{a}$ for high risk groups; $P \leq 0.05$ ). Group 1: normal mice; Group 2: untreated $1 \times 10^{4} 4 \mathrm{~T} 1$ cell (low risk) inoculated mice; Group 3: untreated $1 \times 10^{6} 4 \mathrm{~T} 1$ cell (high risk) mice; Group 4: tamoxifen $\left(1 \mathrm{mg} / \mathrm{kg}\right.$ b.w.) treated $1 \times 10^{4} 4 \mathrm{~T} 1$ cell (low risk) inoculated mice; Group 5: Tamoxifen $\left(1 \mathrm{mg} / \mathrm{kg}\right.$ b.w.) treated $1 \times 10^{6}$ 4T1 cell (high risk) inoculated mice; Group 6: fermented mung bean $\left(200 \mathrm{mg} / \mathrm{kg}\right.$ b.w.) treated $1 \times 10^{4} 4 \mathrm{~T} 1$ cell (low risk) inoculated mice; Group 7: fermented mung bean $(200 \mathrm{mg} / \mathrm{kg}$ b.w. $)$ treated $1 \times 10^{6}$ 4 T1 cell (high risk) inoculated mice; Group 8: fermented mung bean $\left(1000 \mathrm{mg} / \mathrm{kg}\right.$ b.w.) treated $1 \times 10^{4} 4 \mathrm{~T} 1$ cell (low risk) inoculated mice; Group 9: fermented mung bean (1000 mg/kg b.w.) treated $1 \times 10^{6} 4 \mathrm{~T} 1$ cell (high risk) inoculated mice.

soy was found to be linked with increased incidences of cancer in developed countries [1] while high intake of legumes including mung bean during adolescence was reported to protect against breast cancer [17]. Mung bean is another choice of legumes that carries multiple health benefits including having antidiabetic, antioxidant, and hepatoprotective effects [9]. Mung bean seeds and sprouts have been recorded to have in vitro cytotoxic and immunomodulatory effects and germination was found to significantly improve the bioactivities of mung bean seeds $[6,18]$. On the other hand, fermented legume products that contain mung bean as one of the major ingredients have recorded inhibitory effects on the growth of mouse colon cancer xenograft without any side effects [8]. To date, chemopreventive effects on breast cancer solely contributed by fermented mung bean have yet to be reported. Hence, this study was conducted to evaluate the contributions of the antioxidant and the immunostimulation effects of fermented mung beans toward in vivo prevention of breast cancer.

In this study, the transplantable mouse mammary carcinoma $4 \mathrm{~T} 1$ cells that mimic stage IV breast cancer in humans [15] were inoculated in two different cell densities to resemble high $\left(1 \times 10^{6}\right.$ cells $)$ and low $\left(1 \times 10^{4}\right.$ cells $)$ risk. Based on the measurement of the tumor size after inoculation, low and

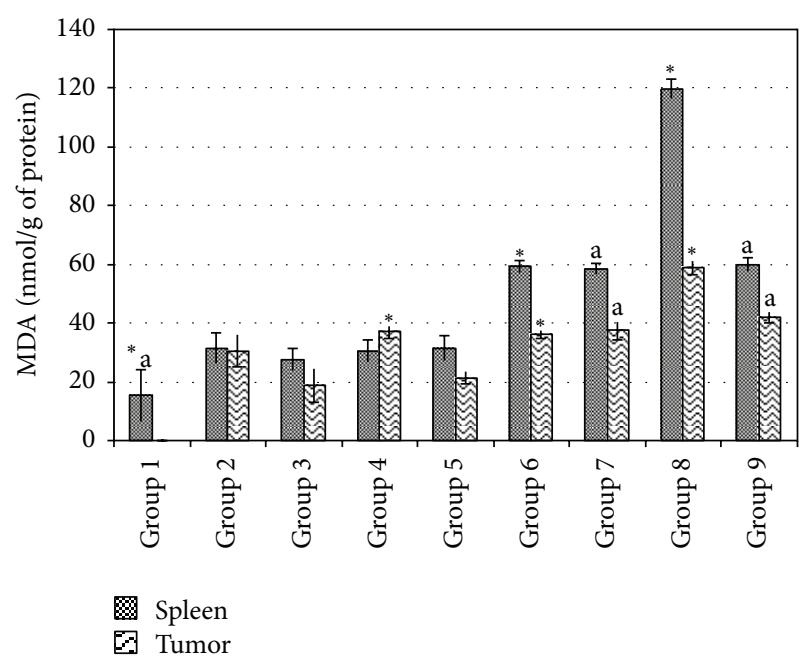

FIGURE 5: MDA level of tumor and spleen homogenate from different treatment groups on day 21 after $4 \mathrm{~T} 1$ cell inoculation. Each value represents the means \pm S.D. for three mice in triplicate each. The differences between the control or treated group and untreated group were determined by one-way ANOVA ( ${ }^{*}$ for low risk groups while ${ }^{a}$ for high risk groups; $P \leq 0.05$ ). Group 1: normal mice; Group 2: untreated $1 \times 10^{4} 4 \mathrm{~T} 1$ cell (low risk) inoculated mice; Group 3: untreated $1 \times 10^{6} 4 \mathrm{~T} 1$ cell (high risk) mice; Group 4: tamoxifen $(1 \mathrm{mg} / \mathrm{kg}$ b.w. $)$ treated $1 \times 10^{4} 4 \mathrm{~T} 1$ cell (low risk) inoculated mice; Group 5: Tamoxifen $\left(1 \mathrm{mg} / \mathrm{kg}\right.$ b.w.) treated $1 \times 10^{6}$ 4 T1 cell (high risk) inoculated mice; Group 6: fermented mung bean $\left(200 \mathrm{mg} / \mathrm{kg}\right.$ b.w.) treated $1 \times 10^{4} 4 \mathrm{~T} 1$ cell (low risk) inoculated mice; Group 7: fermented mung bean $(200 \mathrm{mg} / \mathrm{kg}$ b.w. $)$ treated $1 \times 10^{6}$ $4 \mathrm{~T} 1$ cell (high risk) inoculated mice; Group 8: fermented mung bean $\left(1000 \mathrm{mg} / \mathrm{kg}\right.$ b.w.) treated $1 \times 10^{4} 4 \mathrm{~T} 1$ cell (low risk) inoculated mice; Group 9: fermented mung bean $\left(1000 \mathrm{mg} / \mathrm{kg}\right.$ b.w.) treated $1 \times 10^{6} 4 \mathrm{~T} 1$ cell (high risk) inoculated mice.

high concentrations of fermented mung bean were able to delay the formation of breast cancer tumor in the low risk group of mice with efficacies being comparable to tamoxifen. This result was supported by the histopathology evaluation on the tumor where less mitotic division was observed in the fermented mung bean treated group. However, these treatments were less effective in the high risk group of mice. The tumors in both the high and low risk groups were found to have reduced CD4/CD8 T cell populations, low levels of serum cytokines (IL-2 and IFN- $\gamma$ ), and impaired spleen cell cytotoxicities. Unlike in the untreated mice, increase of the spleen T cell (both CD4 and CD8) population serum T helper 1 cytokines showed activation of cell-mediated immunity by fermented mung bean that consequently helped to delay the formation of the tumor. IL-2 was able to activate the cytotoxicity and IFN- $\gamma$ production of lymphokine-activated killer (LAK) cell that originated from natural killer (NK) and cytolytic CD8 T (CTL) cells. The synergistic effects of IFN$\gamma$ and TNF were the major contributors to the stimulation of LAK cytotoxicity [19]. As a result, high levels of IL-2 and IFN- $\gamma$ were found to inhibit tumor formation $[4,13]$. The improved cytotoxicity effects of splenocytes isolated from the low risk group of fermented mung bean treated mice against Yac-1 cells may have been contributed by the upregulation of 


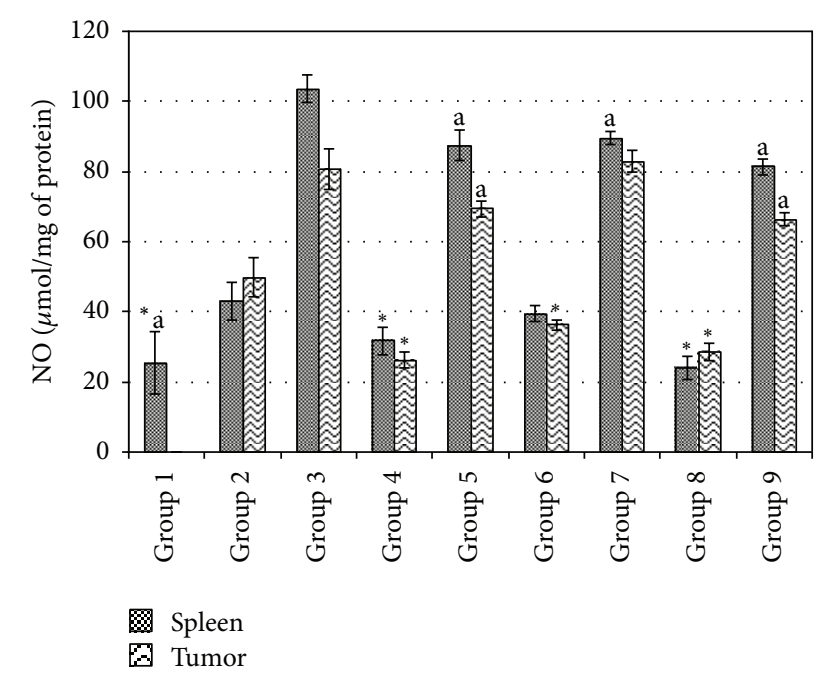

FIGURE 6: NO level of tumor and spleen homogenate from different treatment groups on day 21 following $4 \mathrm{~T} 1$ cell inoculation. Each value represents the means \pm S.D. for three mice in triplicate each. The differences between the control or treated group and untreated group were determined by one-way ANOVA ( ${ }^{*}$ for low risk groups while ${ }^{a}$ for high risk groups; $\left.P \leq 0.05\right)$. Group 1: normal mice; Group 2: untreated $1 \times 10^{4} 4 \mathrm{~T} 1$ cell (low risk) inoculated mice; Group 3: untreated $1 \times 10^{6} 4 \mathrm{~T} 1$ cell (high risk) mice; Group 4: tamoxifen $\left(1 \mathrm{mg} / \mathrm{kg}\right.$ b.w.) treated $1 \times 10^{4} 4 \mathrm{~T} 1$ cell (low risk) inoculated mice; Group 5: Tamoxifen $(1 \mathrm{mg} / \mathrm{kg}$ b.w. $)$ treated $1 \times 10^{6}$ $4 \mathrm{~T} 1$ cell (high risk) inoculated mice; Group 6: fermented mung bean $\left(200 \mathrm{mg} / \mathrm{kg}\right.$ b.w.) treated $1 \times 10^{4} 4 \mathrm{~T} 1$ cell (low risk) inoculated mice; Group 7: fermented mung bean $(200 \mathrm{mg} / \mathrm{kg}$ b.w. $)$ treated $1 \times 10^{6}$ $4 \mathrm{~T} 1$ cell (high risk) inoculated mice; Group 8: fermented mung bean $\left(1000 \mathrm{mg} / \mathrm{kg}\right.$ b.w.) treated $1 \times 10^{4} 4 \mathrm{~T} 1$ cell (low risk) inoculated mice; Group 9: fermented mung bean $\left(1000 \mathrm{mg} / \mathrm{kg}\right.$ b.w.) treated $1 \times 10^{6} 4 \mathrm{~T} 1$ cell (high risk) inoculated mice.

IL- 2 and IFN- $\gamma$ production by the extract. Thus, activation of T cells to produce Th 1 cytokines (IL- 2 and IFN- $\gamma$ ) that further activated cytotoxicity of splenocytes may have contributed to the lower mitotic division in the tumor.

Overexpression of enzymic and nonenzymic antioxidants was commonly used by malignant cells including breast cancer cells to escape from CTL identification [20]. Moreover, decrease of MDA level was related to severity of breast cancer [21]. Our result was similar with this finding where overstimulation of antioxidant and $\mathrm{NO}$ accompanied with decline of MDA level was found in the untreated mice. $\mathrm{NO}$ is an important inflammatory mediator that links to the tumorigenesis and angiogenesis of breast cancer via the Akt signalling pathway [22]. Many chemopreventive agents including tamoxifen, soy, and green tea were also found to induce anticarcinogenic effects using lipid peroxidationrelated pathway besides estrogen and inflammation pathway [21]. For example, isoflavones in fermented soy bean induced breast cancer cell death via promoting generation of ROS which subsequently arrest the cell growth besides carrying antioxidant effect against the normal cell [21]. Thus, increase of lipid peroxidation level by fermented mung bean and tamoxifen treatment in this study may contribute to the
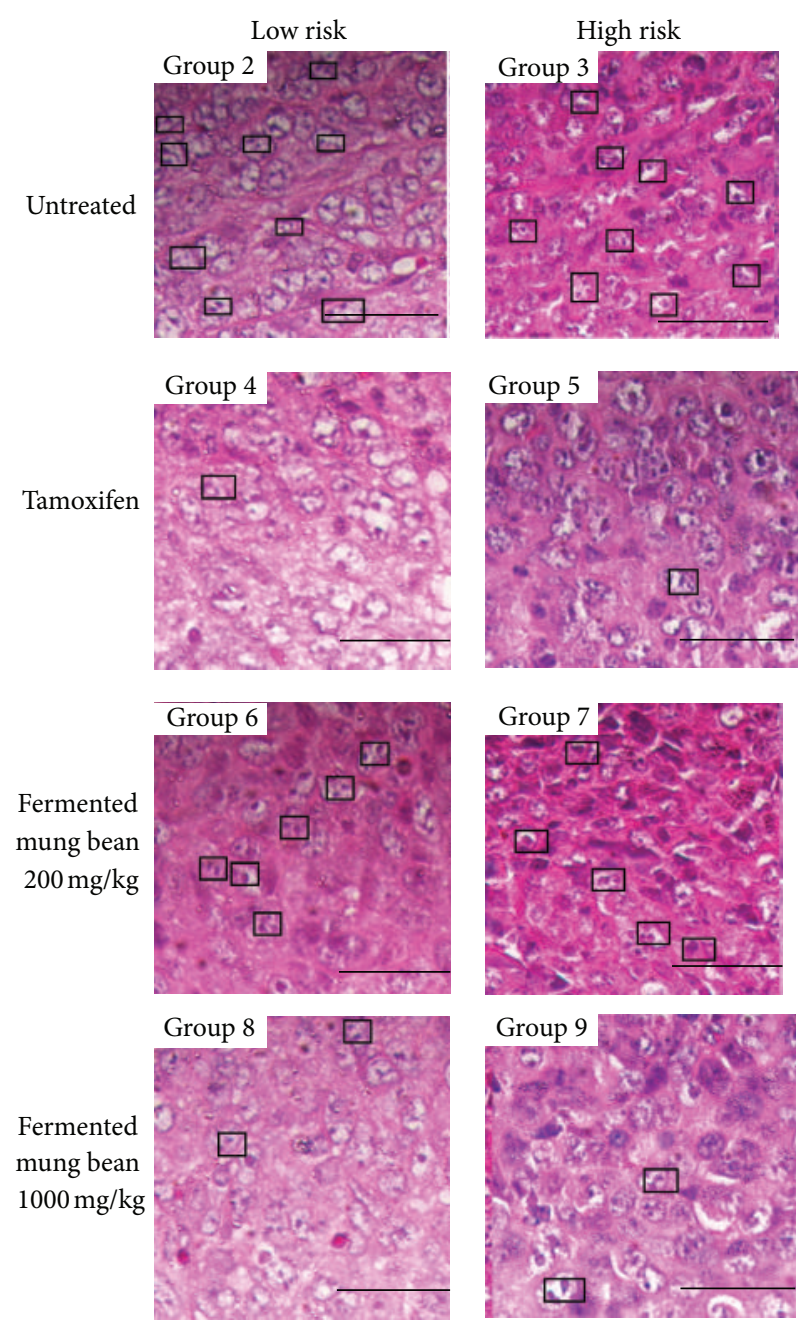

Figure 7: Histological emergence of the 4T1 tumor from Group 2 to Group 9. Boxes indicate cells under mitotic division. Black bars signify $200 \mu \mathrm{m}$ (magnification 40x). Group 2: untreated $1 \times 10^{4}$ 4T1 cell (low risk) inoculated mice; Group 3: untreated $1 \times 10^{6}$ $4 \mathrm{Tl}$ cell (high risk) mice; Group 4 : tamoxifen ( $1 \mathrm{mg} / \mathrm{kg}$ b.w.) treated $1 \times 10^{4} 4 \mathrm{~T} 1$ cell (low risk) inoculated mice; Group 5: Tamoxifen $\left(1 \mathrm{mg} / \mathrm{kg} \mathrm{b.w.)}\right.$ treated $1 \times 10^{6} 4 \mathrm{~T} 1$ cell (high risk) inoculated mice; Group 6: fermented mung bean $\left(200 \mathrm{mg} / \mathrm{kg}\right.$ b.w.) treated $1 \times 10^{4}$ $4 \mathrm{~T} 1$ cell (low risk) inoculated mice; Group 7: fermented mung bean $\left(200 \mathrm{mg} / \mathrm{kg}\right.$ b.w.) treated $1 \times 10^{6} 4 \mathrm{~T} 1$ cell (high risk) inoculated mice; Group 8: fermented mung bean $(1000 \mathrm{mg} / \mathrm{kg}$ b.w. $)$ treated $1 \times 10^{4}$ $4 \mathrm{~T} 1$ cell (low risk) inoculated mice; Group 9: fermented mung bean $\left(1000 \mathrm{mg} / \mathrm{kg}\right.$ b.w.) treated $1 \times 10^{6} 4 \mathrm{~T} 1$ cell (high risk) inoculated mice.

reduction of mitotic division in the treated group. In this study, treatment by fermented mung bean and tamoxifen successfully suppressed the overexpression of antioxidant level of spleen and reduced the NO level of the tumor. Reduction of NO level that indicated anti-inflammatory effect has been previously reported as a major event in the chemopreventive effect of resveratrol [23]. Hence, the lipid peroxidation and anti-inflammatory effects of fermented mung bean may indirectly reduce the cancer progression of the $4 \mathrm{~T} 1$ cells in this study. 
In this study, fermented mung bean in a dosagedependent manner has delayed the formation of breast cancer and reduced the mitotic division of the tumor through stimulation of $\mathrm{T}$ cell cytokine production (IL-2 and IFN$\gamma$ ) and cytotoxicity. Lower antioxidant and NO levels were observed as compared to the untreated mice from the low risk group. However, fermented mung bean induced poorer chemopreventive effects against mice inoculated with high concentrations of $4 \mathrm{~T} 1$ cells. Thus, further studies should focus on the effects of long-term consumption of fermented mung beans and evaluation of the detailed mechanism of the chemopreventive action of fermented mung bean against breast cancer.

\section{Acknowledgments}

This study was supported by the e-Science Fund (Ministry of Agriculture, Malaysia). The authors would like to thank Professor S. G. Tan for proofreading this paper.

\section{References}

[1] N. J. Nelson, "Migrant studies aid the search for factors linked to breast cancer risk," Journal of the National Cancer Institute, vol. 98, no. 7, pp. 436-438, 2006.

[2] S. U. Luk, T. K. W. Lee, J. Liu et al., "Chemopreventive effect of PSP through targeting of prostate cancer stem cell-like population," PLoS ONE, vol. 6, article e19804, no. 5, 2011.

[3] S. V. Law, F. Abu Bakar, D. Mat Hashim, and A. Abdul Hamid, "Popular fermented foods and beverages in Southeast Asia," International Food Research Journal, vol. 18, no. 2, pp. 475-484, 2011.

[4] A. de Moreno de LeBlanc, C. Matar, N. LeBlanc, and G. Perdigón, "Effects of milk fermented by Lactobacillus helveticus R389 on a murine breast cancer model," Breast Cancer Research, vol. 7, no. 4, pp. R477-R486, 2005.

[5] L. O. Wongekalak, P. Sakulsom, K. Jirasripongpun, and P. Hongsprabhas, "Potential use of antioxidative mungbean protein hydrolysate as an anticancer asiatic acid carrier," Food Research International, vol. 44, no. 3, pp. 812-817, 2011.

[6] R. R. Hafidh, A. S. Abdulamir, F. A. Bakar, F. A. Jalilian, F. Abas, and Z. Sekawi, "Novel molecular, cytotoxical, and immunological study on promising and selective anticancer activity of Mung bean sprouts," BMC Complementary and Alternative Medicine, vol. 12, article 208, 2012.

[7] L. O. Wongekalak, P. Sakulsom, K. Jirasripongpun, and P. Hongsprabhas, "Potential use of antioxidative mungbean protein hydrolysate as an anticancer asiatic acid carrier," Food Research International, vol. 44, no. 3, pp. 812-817, 2011.

[8] J.-S. Chia, J.-L. Du, M. S. Wu et al., "Fermentation production of soybean, black bean, and green bean mixture induces apoptosis in a wide variety of cancer cell," Integrative Cancer Therapies, 2013.

[9] N. M. Ali, H. M. Yusof, K. Long et al., "Antioxidant and hepatoprotective effect of aqueous extract of germinated and fermented mung bean on ethanol-mediated liver damage," BioMed Research International, vol. 2013, Article ID 693613, 9 pages, 2013.

[10] Q. Huang, C. L. Zhu, C. H. Lium, F. Xie, K. Zhu, and S. Y. Hu, "Gamma-aminobutyric acid binds to $\mathrm{GABA}(\mathrm{B})$ receptor to inhibit cholangiocarcinoma cells growth via the JAK/STAT3 pathway," Digestive Diseases and Sciences, vol. 58, no. 3, pp. 734743, 2013.

[11] C. H. Oh and S. H. Oh, "Effects of germinated brown rice extracts with enhanced levels of GABA on cancer cell proliferation and apoptosis," Journal of Medicinal Food, vol. 7, no. 1, pp. 19-23, 2004.

[12] A. Martinez, E. Muniz, I. Iglesias, J. M. Teijon, and M. D. Blanco, "Enhanced preclinical efficacy of tamoxifen developed as alginate-cysteine/disulphide bond reduced albumin nanoparticles," International Journal of Pharmaceutics, vol. 436, no. 1-2, pp. 574-581, 2012.

[13] S. K. Yeap, A. R. Omar, A. M. Ali, W. Y. Ho, B. K. Beh, and N. B. Alitheen, "Immunomodulatory effect of Rhaphidophora korthalsiion natural killer cell cytotoxicity," Evidence-Based Complementary and Alternative Medicine, vol. 2012, Article ID 786487, 2012.

[14] R. Siegel, D. Naishadham, and A. Jemal, "Cancer statistics, 2012," CA: A Cancer Journal for Clinicians, vol. 62, pp. 10-29, 2012.

[15] M. S. Baliga, S. Meleth, and S. K. Katiyar, "Growth inhibitory and antimetastatic effect of green tea polyphenols on metastasis-specific mouse mammary carcinoma $4 \mathrm{~T} 1$ cells in vitro and in vivo systems," Clinical Cancer Research, vol. 11, no. 5, pp. 19181927, 2005.

[16] Y. J. Surh, "Cancer chemoprevention with dietary phytochemicals," Nature Reviews Cancer, vol. 3, no. 10, pp. 768-780, 2003.

[17] X. O. Shu, F. Jin, Q. Dai et al., "Soyfood intake during adolescence and subsequent risk of breast cancer among Chinese women," Cancer Epidemiology Biomarkers and Prevention, vol. 10, no. 5, pp. 483-488, 2001.

[18] D. K. Kim, S. C. Jeong, S. Gorinstein, and S. U. Chon, “Total polyphenols, antioxidant and antiproliferative activities of different extracts in mungbean seeds and sprouts," Plant Foods for Human Nutrition, vol. 67, no. 1, pp. 71-75, 2012.

[19] A. S. F. Chong, P. Scuderi, W. J. Grimes, and E. M. Hersh, "Tumor targets stimulate IL-2 activated killer cells to produce interferon- $\gamma$ and tumor necrosis factor," Journal of Immunology, vol. 142, no. 6, pp. 2133-2139, 1989.

[20] C. P. Rajneesh, A. Manimaran, K. R. Sasikala, and P. Adaikappan, "Lipid peroxidation and antioxidant status in patients with breast cancer," Singapore Medical Journal, vol. 49, no. 8, pp. 640$643,2008$.

[21] M. Gago-Dominguez, X. Jiang, and J. E. Castelao, "Lipid peroxidation, oxidative stress genes and dietary factors in breast cancer protection: a hypothesis," Breast Cancer Research, vol. 9, no. 1, article 201, 2007.

[22] L. A. Ridnour, K. M. Barasch, A. N. Windhausen et al., "Nitric oxide synthase and breast cancer: role of TIMP-1 in NOmediated Akt activation," PLoS ONE, vol. 7, article e44081, 2012.

[23] A. M. El-Mowafy, M. E. El-Mesery, H. A. Salem, M. M. AlGayyar, and M. M. Darweish, "Prominent chemopreventive and chemoenhancing effects for resveratrol: unraveling molecular targets and the role of C-reactive protein," Chemotherapy, vol. 56, no. 1, pp. 60-65, 2010. 


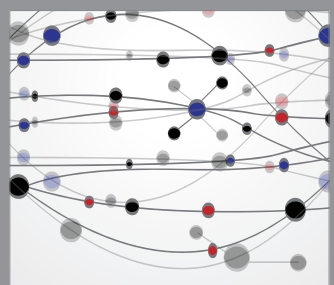

The Scientific World Journal
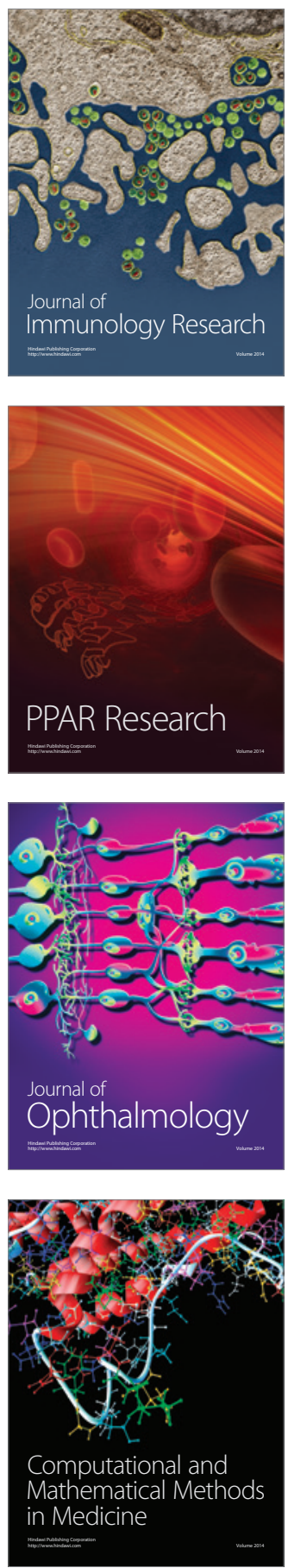

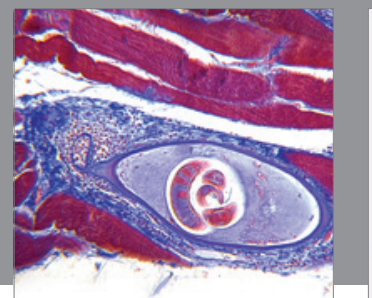

Gastroenterology

Research and Practice
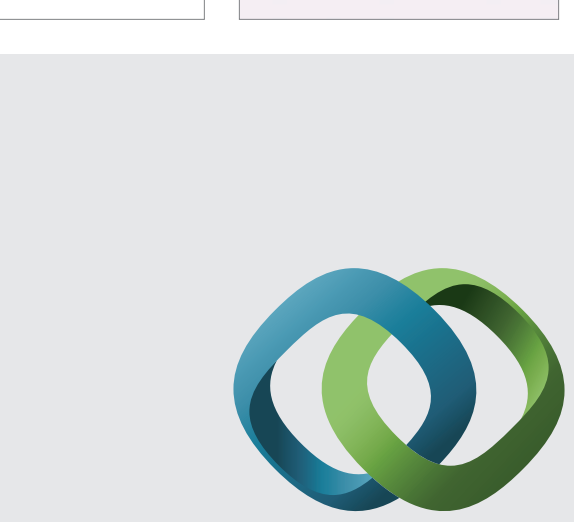

\section{Hindawi}

Submit your manuscripts at

http://www.hindawi.com
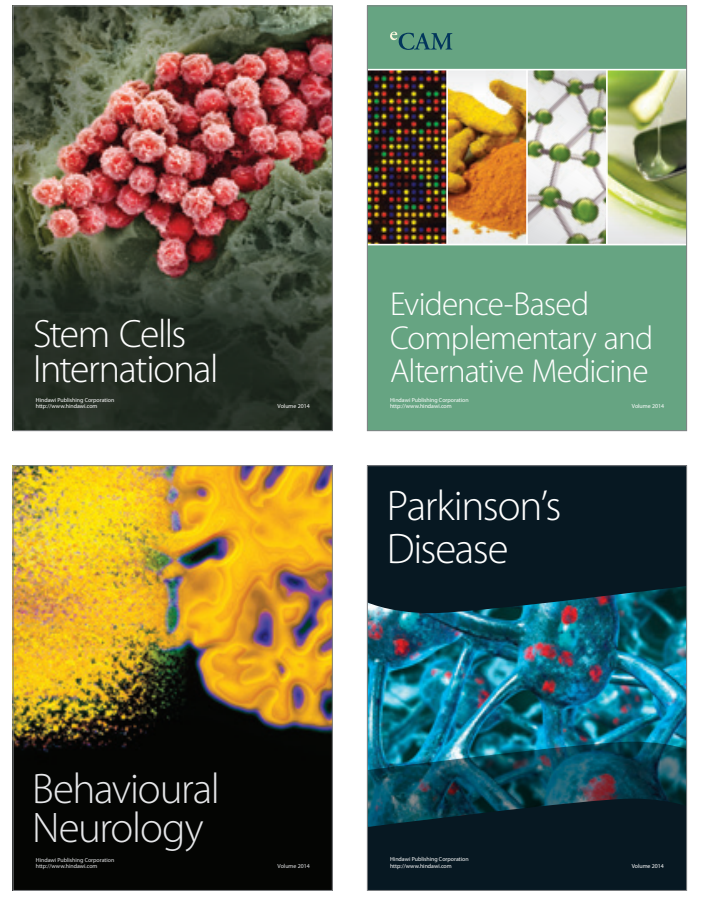
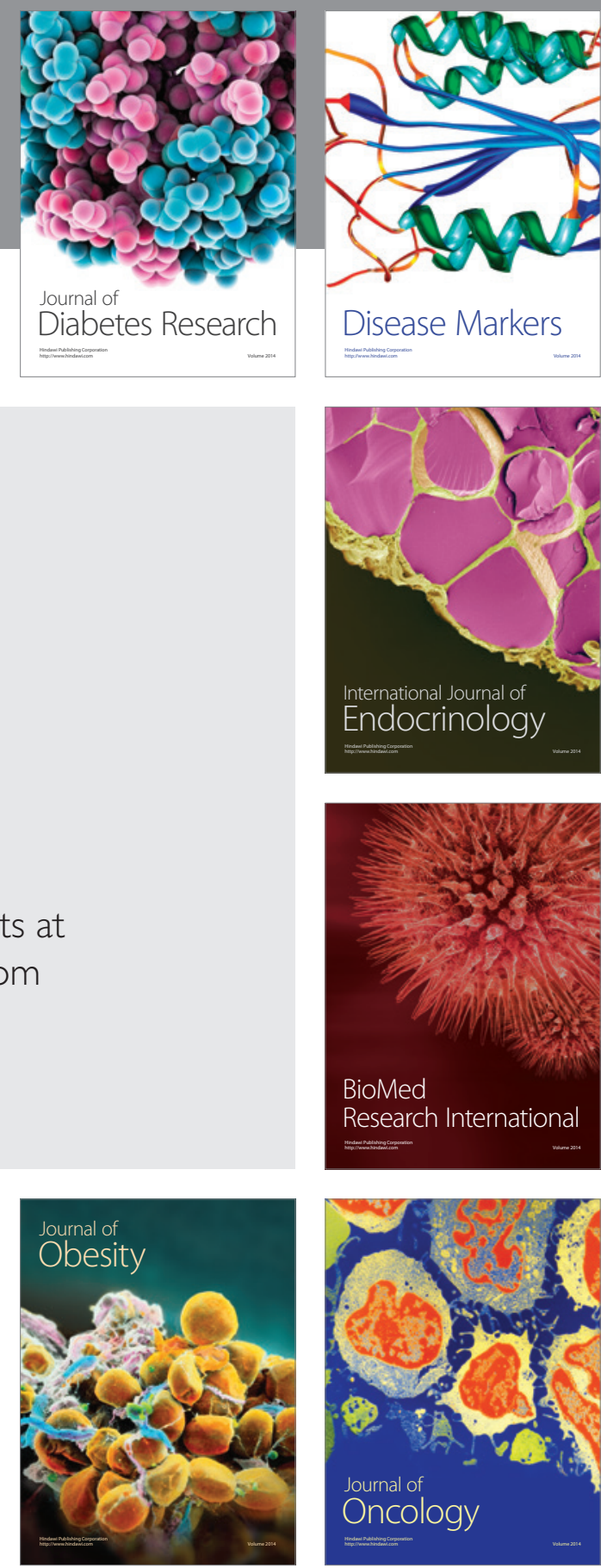

Disease Markers
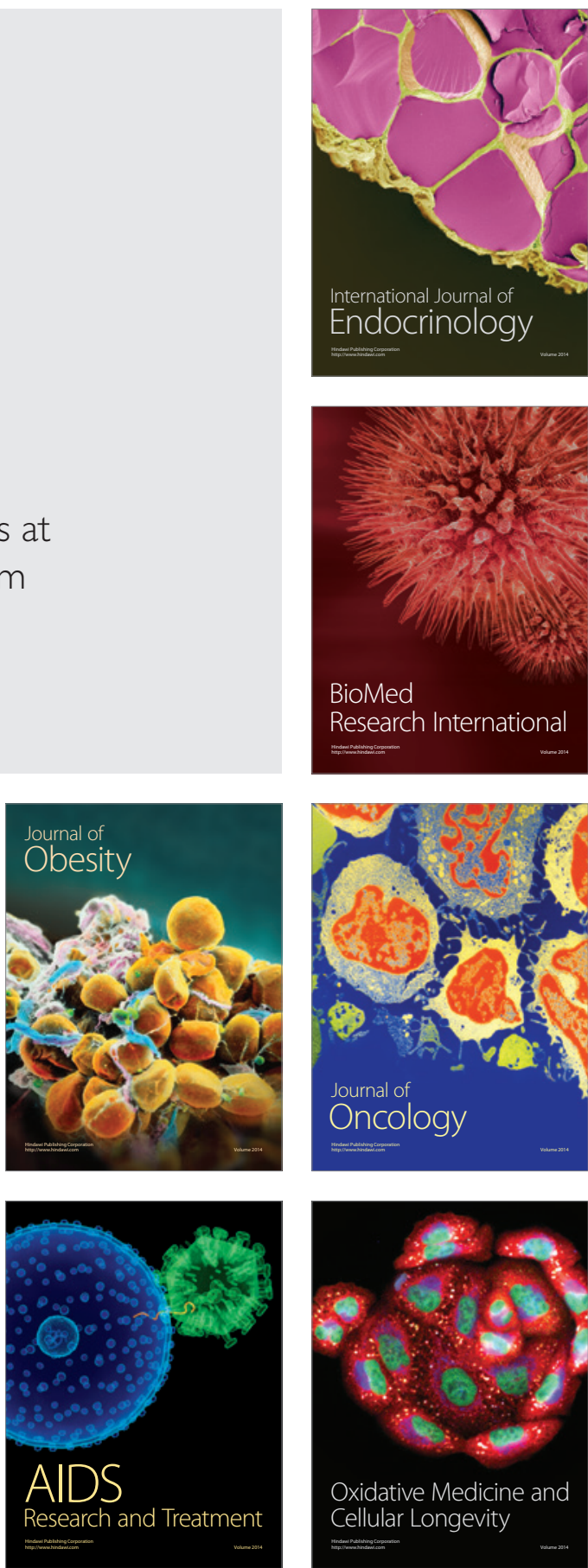